\title{
Comparative analysis of financial Production Sharing Contract (PSC) cost recovery with PSC gross split: Case study in one of the contractor SKK Migas
}

\author{
Budhi Refa Anjani ${ }^{1 *}$, Imam Baihaqi ${ }^{2}$ \\ ${ }^{1}$ Master's Program in Management of Technology, Institute Technology Sepuluh Nopember, Surabaya, Indonesia \\ ${ }^{2}$ Departement of Industrial Engineering, Institute Technology Sepuluh Nopember, Surabaya, Indonesia
}

\section{Keywords}

PSC

Gross split

Net Present Value (NPV)

Internal Rate of Return (IRR)

Received: 23 January 2018

Accepted: 22 February 2018

Published: 18 April 2018

\begin{abstract}
This research explores two schemes of oil and gas PSC. First, Cost Recovery (old scheme) that the investor earned a production cost refund. At the same time, the second scheme is Gross Split (new scheme), which is the productionsharing system without the cost of recovery. The Gross Split scheme was implemented by the Minister of Energy and Mineral Resources, Ignatius Jonan, in early 2017 in response to the concerns of People's Representative Council (DPR) Commission VII that the Cost Recovery scheme was no longer profitable for the Government. Thus, there should be a new one that is better, beneficial, yet attractive to investors to entrust the Indonesian oil and gas business. The study was conducted at PT XYZ, the first PSC Company which implemented the Gross Split scheme after its contract period under the Cost Recovery scheme ended in January 2017. The study focuses on two cases of offshore oil and gas development projects, $\mathrm{X}$ and $\mathrm{Y}$, by using economic capital budgeting indicators, such as NPV, IRR, and Payback Period. In addition, oil and gas fiscal calculations are done equally with Net Contractor Take and Government Take, then analyzed the variable's sensitivity that affects its economic project. The results showed that Gross Split scheme projects have better NPV and IRR values than the Cost Recovery scheme. As for the Payback Period, both schemes had the same value. This means that the economic value of the Gross Split scheme project is better. However, it turns out that the Government Takes value is much smaller. While from the sensitivity analysis, the amount of production and price is very sensitive to both economic projects and the widespread on the Gross Split scheme. It can be concluded that the PSC Gross Split scheme will benefit the Contractor if it is accomplished with good planning of Work Program \& Budgeting (WPB), accurate calculation of oil and gas reserve, timely development of oil and gas facilities, along with the efficient use of production costs. For the Government, although the income is smaller, on the other hand, it is no longer burdened with cost recovery of production, which has been disrupting the state's finance in the development of exploration and domestic oil and gas production.
\end{abstract}

(C) 2018 The Author(s). Published by TAF Publishing.

\section{INTRODUCTION}

Some backgrounds affecting the Indonesian government change the production sharing scheme from cost recovery to the Gross Split scheme, which are: the lack of exploration activities in Indonesia resulting in declining lifting and crude oil production (Figure 1-left), declining world oil prices since 2014 were US29/barrel being the lowest point oil prices from the previous range of US100/barrel (Figure 1-Right), and therefore, the country's revenues from the natural resources sector declined every year, as well as the cost of recovery compared to the net government take which burdened the government.

This new scheme applies to Indonesia oil and gas contractors where the contract has been expired and will be renewed with the government. Under government regulation (Indonesian Ministry of Energy and Mineral Resources, 2017), with the changing of terms, the study was conducted to compare the production sharing between cost recovery and gross split in economic calculation of upstream business of oil and gas.

\footnotetext{
*corresponding author: Budhi Refa Anjani

†email: budhirefa@gmail.com
} 

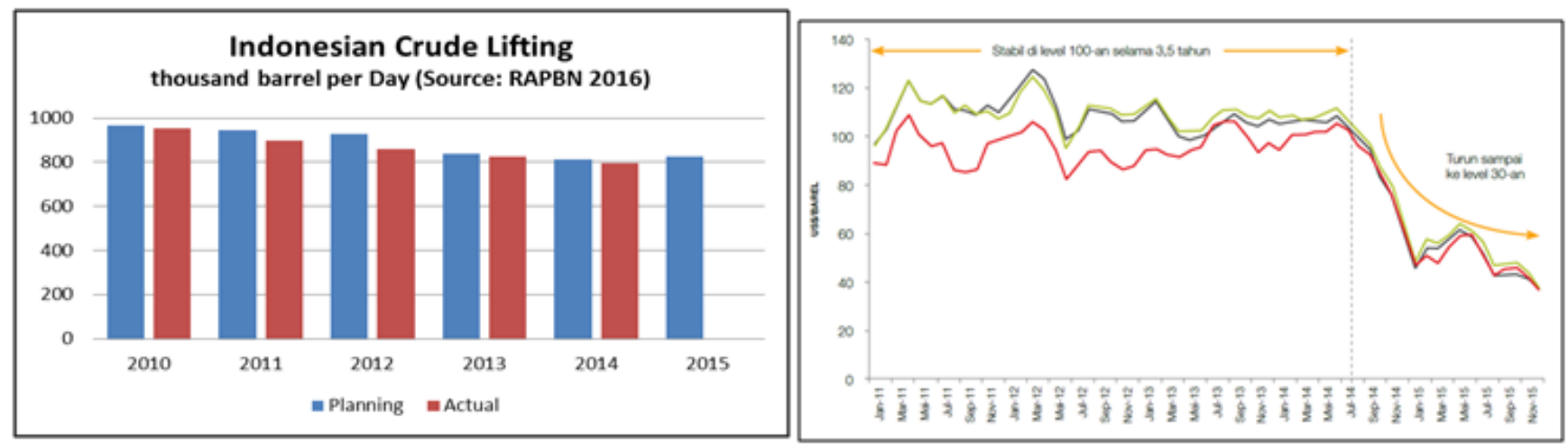

FIGURE 1. Indonesian lifting crude 2010-2015 (Left) (Kementrian, 2016), comparison WTI, brent and Indonesian crude prices 2011-2015 (Right) (BP, 2016)

\section{LITERATURE REVIEW}

\section{Production Sharing Contract in Indonesia}

Important phases of the oil and gas industry in Indonesia can be grouped into three eras: the Dutch colonial era, the early era of independence, and the era of mode $5 \mathrm{rn}$ industry. The Dutch colonial era marked the first commercial oil dis- covery in June Yoshino and Alekhina (2016) who had previously obtained the concession rights of the Langkat sultan in the Telaga Said area of Langkat. The discovery of this oil served as the momentum of the establishment of the Dutch oil company (Royal Shell) in 1890 (Lubiantara, 2012; Yoshino \& Alekhina, 2016).

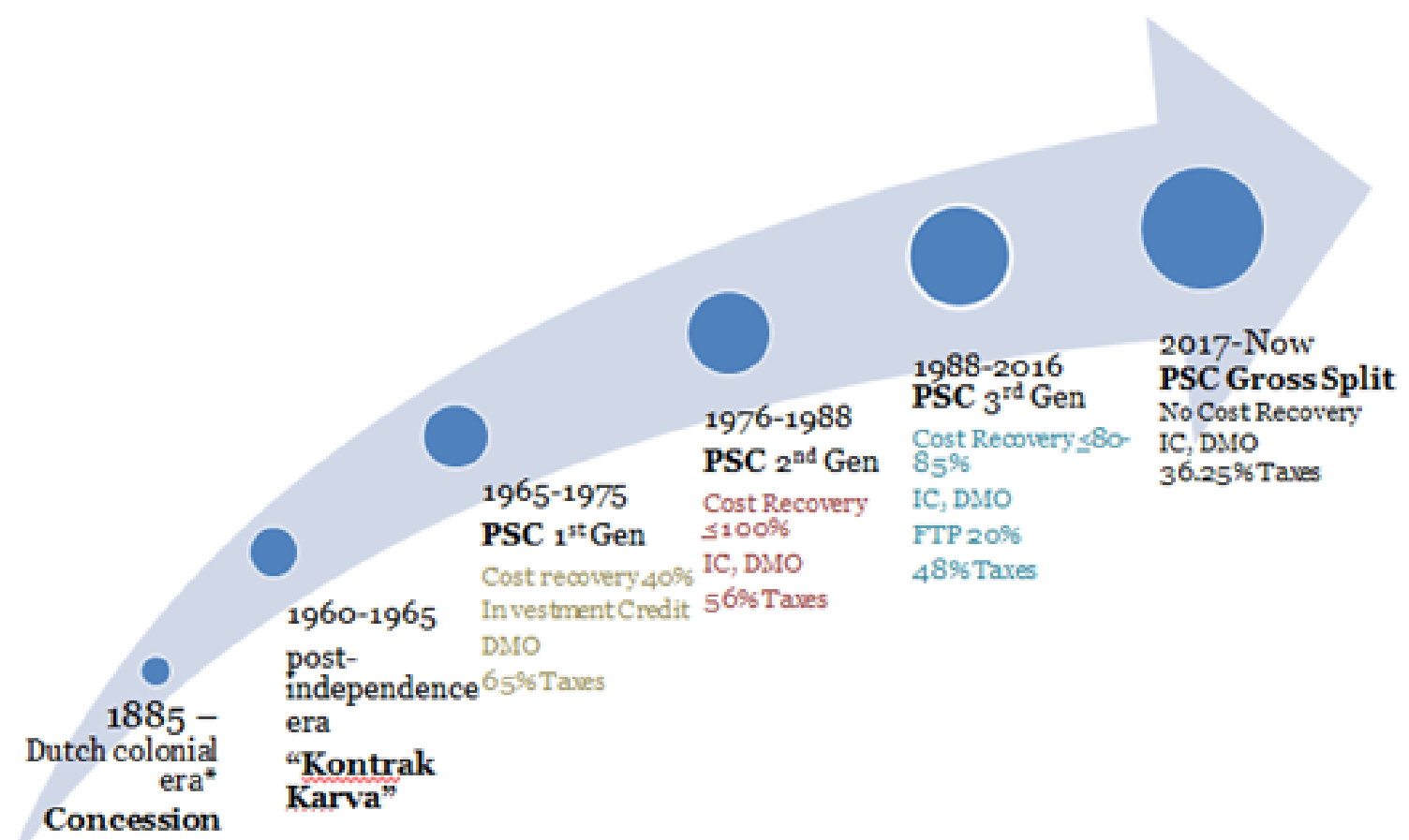

FIGURE 2. Indonesia production oil and gas-share transformation (Nasir, 2014)

In 1965, there was a political turmoil in Indonesia with the G30S/PKI rebellion which resulted in the replacement of the regime into the "orde baru" under President Suharto. In 1966, Dr. Ibnu Sutowo, who became President Director of PERMINA, was appointed as Minister of Oil and Gas, then was criticized of "Kontrak Karya" which considered the system to be nothing other than the Concession system. For him, the most fundamental difference between the concession system and the non-concession system was the ownership aspect (Lubiantara, 2012). There was birth of a profitsharing system whereby the two parties involved (host Government and foreign oil company) share the oil and gas production, not the share of oil and gas sales as done in the concession system. In that situation, the first indepen- 
dent small oil company in cooperation with the PSC system was the Independence Indonesian American Oil Company (IIAPCO) in 1966, followed by four other companies: Japan Petroleum Exploration Company (JAPEX), Refining Associates Ltd. Canada (REFICAN), Kyushu Oil Development Ltd., and Asamera Oil Indonesia Ltd. Furthermore, this contract model became the embryo of the first generation PSC. There are more petroleum fiscal systems in the world than are counties. This is because many countries negotiate terms. Thus, one contractor may have different terms than another in the same country. Furthermore, in many countries, there are numerous vintages of contract in force at any given time as a result of the evolution of the fiscal system. Some countries use more than one system during transition periods when they are introducing new terms. Some countries offer concessionary arrangements as well as service or production sharing contract (Johnston, 2007).

\section{Who has "title" to mineral resources}

Under royalti/tax system, title to hydrocarbon can be transferred at the well head

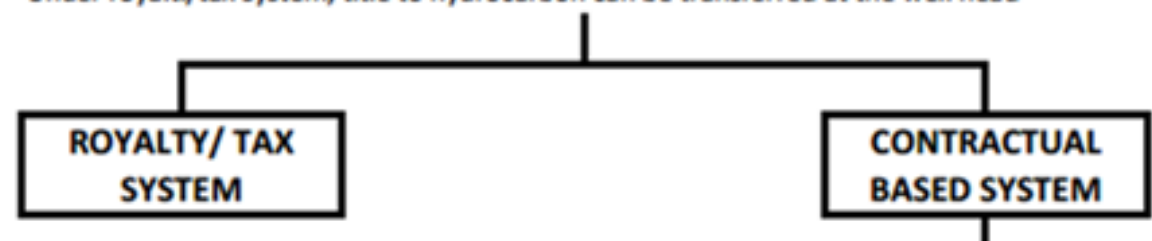

Are "reimbusement" and "Remuniration"

in "cash" (SA) or in "kind" (PSC)

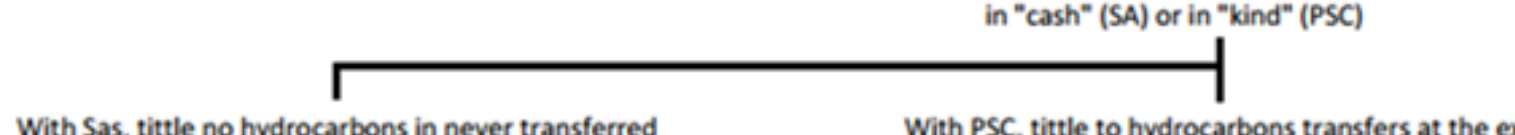

With Sas, tittle no hydrocarbons in never transferred

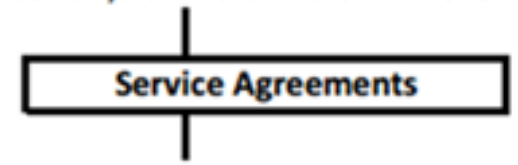

Is remuniration based upon a flat fee (pure) of profit (risk)?

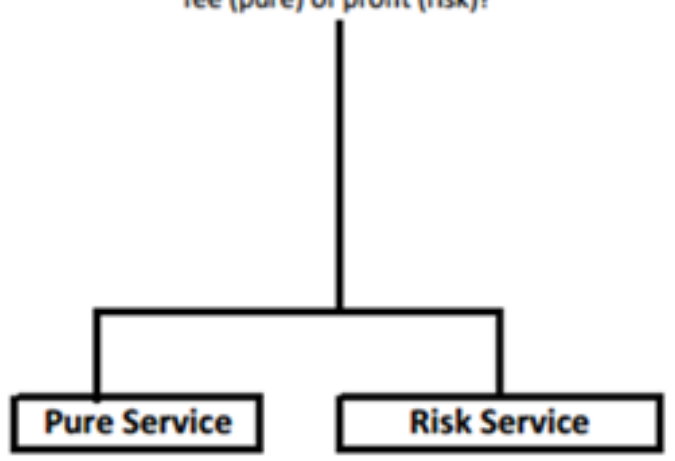

With PSC, tittle to hydrocarbons transfers at the export point

Production Sharing Contract

What is shared? Gross Production (Peruvian type PSC) or Profit oil (Indonesian type PSC)

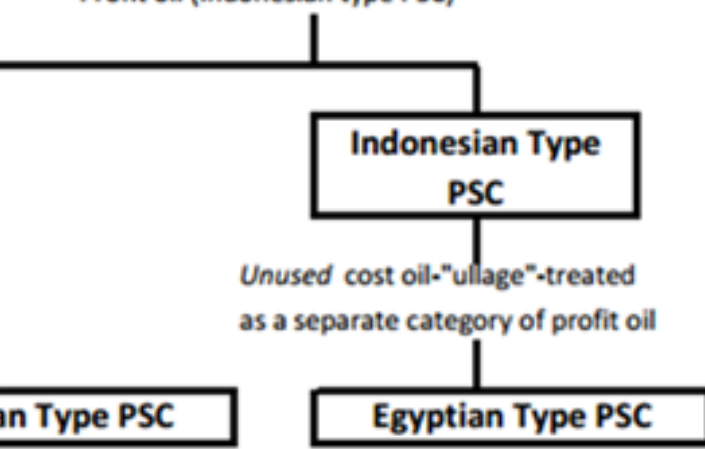

FIGURE 3. Classification of oil and gas fiscal regime (Johnston, 2007)

The increase in current consumption for higher future consumption is the reason for saving. What you do with savings to make them increase over time is an investment (Reilly \& Brown, 2002). At the heart of any new investment is the contract and, more than ever, it is essential that contracts be balanced-balanced in the sense that each party, both the host government and the private investor, is bringing something to the table that is recognized and respected. Willingness to put real money at risk in the midst of risk capital scarcity can no longer be taken for granted and must be attractive. The deal, therefore, also needs to be balanced over time, since a deal that is balanced today can easily become unbalanced in the future (Machmud, 2000). At oil and gas companies, including those in Indonesia with production sharing system, only the four most commonly used are: NPV, IRR, Profitibility Index (PI), and "Payback Period".

With the use of double declining balance method with seven-year economic life for the assets of production facilities and the straight-line method with a five-year economic life for office equipment assets, the oil and gas prod- 
uct sharing contract in Indonesia actually provides accelerated depreciation due to asset - these assets can generally provide benefits longer than those specified above. By accelerating this depreciation, it will also increase the cash flow for the production sharing contractor that manages the oil or gas field. Better cash flow will certainly also make the economics of oil and gas investment with the system of profit sharing in Indonesia better when compared with systems in other countries that use depreciation methods based on production units, especially if the oil or gas field has a large reserve and able to produce more than seven years (Galawidya, 2008).
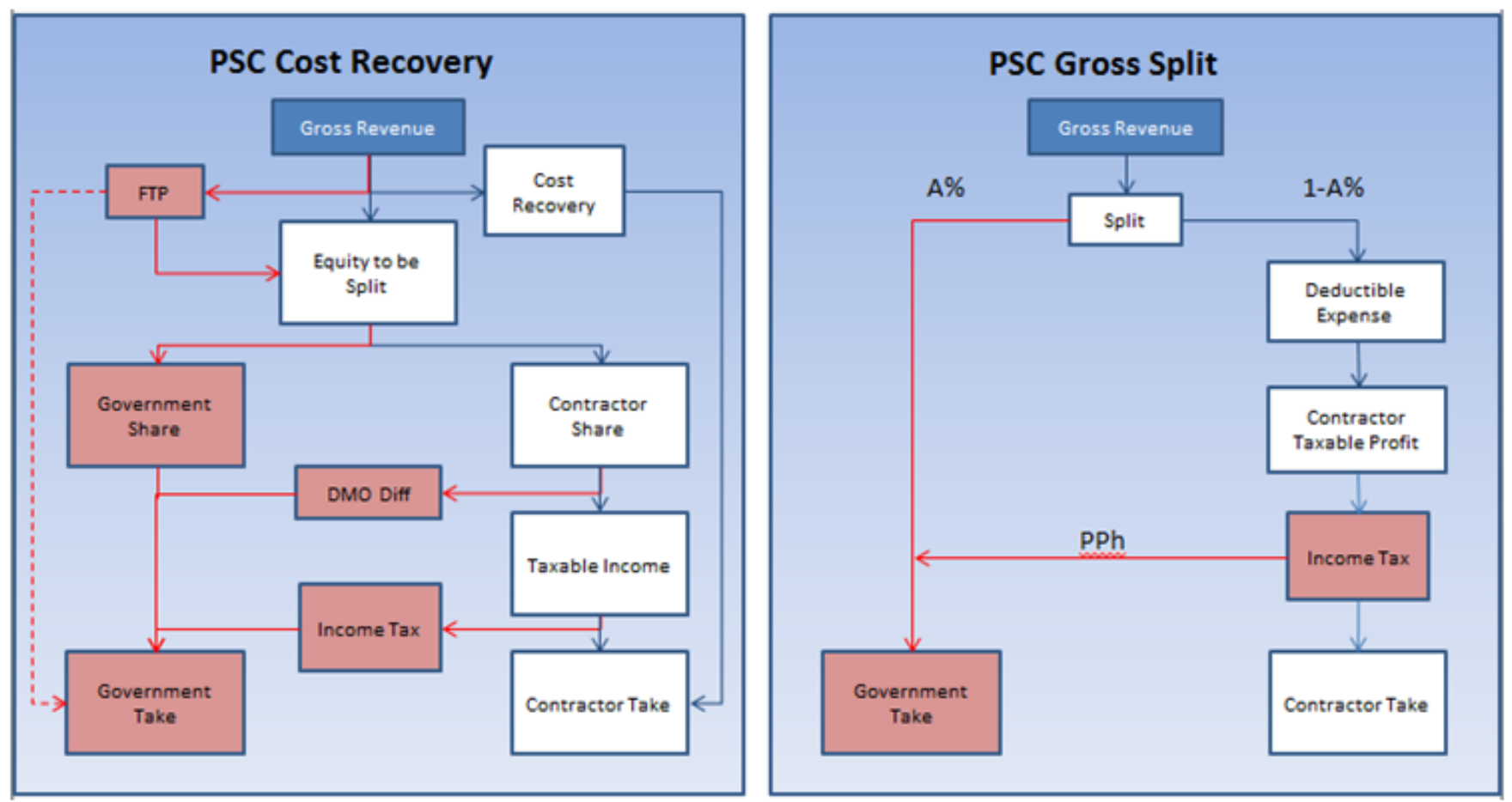

FIGURE 4. Comparison between PSC cost recovery, left- (Ariyati, 2010) and PSC gross split (Partowidagdo, 2009)

\section{PSC Gross Split}

The most significant difference between the two schemes is the presence and absence of cost recovery, and the government is no longer burdened with cost recovery from the oil and gas development. By the new gross split scheme, we can gross split scheme government getting certainty of gross revenue (Base split \pm variable split \pm progressive split).

TABLE 1. Base split (Indonesian Ministry of

\begin{tabular}{lll}
\multicolumn{3}{c}{ Energy and Mineral Resources, 2017) } \\
\hline \hline Base Split & Government & Contractor \\
\hline \hline Oil & $57 \%$ & $43 \%$ \\
Gas & $52 \%$ & $48 \%$ \\
\hline \hline
\end{tabular}

Under (Indonesian Ministry of Energy and Mineral Resources, 2017), production share between government and contractor is known as "split", and the "split" is affected by variable components (field status, field location, $\mathrm{H}_{2} \mathrm{~S}$ and $\mathrm{CO}_{2}$ content, well depth, domestic content) and progressive components (cumulative production and oil prices). 
TABLE 2. Variable split (Indonesian Ministry of Energy and Mineral Resources, 2017)

\begin{tabular}{|c|c|c|c|}
\hline No. Characteristic & Parameter & $\begin{array}{c}\text { Contractor Correction } \\
\text { Split (\%) } \\
\end{array}$ & Remarks \\
\hline \multirow[t]{4}{*}{1 Field status } & POD I & 5 & $\begin{array}{l}\text { Plan of Development (POD) The first } \\
\text { developed within a working area } \\
\text { that changed the status } \\
\text { of exploration work } \\
\text { area to Production }\end{array}$ \\
\hline & POD II & 0 & $\begin{array}{l}\text { (POD) further developed in } \\
\text { one working area. }\end{array}$ \\
\hline & POD III & 0 & $\begin{array}{l}\text { Further development } \\
\text { of existing (POD) } \\
\text { developed within a } \\
\text { working area and/or in } \\
\text { tie-in to existing } \\
\text { field/production facilities }\end{array}$ \\
\hline & No POD & $(-5.0)$ & $\begin{array}{l}\text { Continue production in one Work } \\
\text { Area termination without going } \\
\text { through a POD mechanism }\end{array}$ \\
\hline \multirow[t]{6}{*}{$\begin{array}{l}2 \text { Field location } \\
(* h=\text { sea meters depth })\end{array}$} & Onshore & 0 & $\begin{array}{l}\text { Places where oil or gas wells } \\
\text { are located onshore }\end{array}$ \\
\hline & Offshore $(0<h \leq 20)$ & 8 & \\
\hline & Offshore $(20<h \leq 50)$ & 10 & \\
\hline & Offshore $(50<h \leq 150)$ & 12 & \\
\hline & Offshore $(150<h \leq 1000)$ & 14 & \\
\hline & Offshore $(>1000)$ & 16 & \\
\hline 3 Depth of & $\leq 2500$ & 0 & The vertical depth of the oil and gas \\
\hline reservoir $(\mathrm{m})$ & $>2500$ & 1 & wells where hydrocarbons are found \\
\hline \multirow[t]{2}{*}{$\begin{array}{l}4 \text { Availability of } \\
\text { Supporting Infrastructure }\end{array}$} & Well Development & 0 & $\begin{array}{l}\text { Availability of oil and gas supporting } \\
\text { infrastructure at work area location } \\
\text { (e.g., Road, Port, and Others) }\end{array}$ \\
\hline & New Frontier & 2 & $\begin{array}{l}\text { A work area that is supporting } \\
\text { infrastructure not available yet }\end{array}$ \\
\hline \multirow[t]{2}{*}{5 Reservoir Type } & Conventional & 0 & $\begin{array}{l}\text { A Reservoir of oil and gas located } \\
\text { in rocks other than "coal" and "shale", } \\
\text { commonly present in sand } \\
\text { and carbonate rocks }\end{array}$ \\
\hline & Non-Conventional & 16 & $\begin{array}{l}\text { A Reservoir of oil and gas deposited } \\
\text { in coal/coal and rock layers "shale" }\end{array}$ \\
\hline \multirow[t]{6}{*}{$6 \mathrm{CO}_{2}$ content $(\%)$} & $<5$ & 0 & Carried carbon dioxide and must \\
\hline & $5 \leq x<10$ & 0.5 & be separated from natural gas to \\
\hline & $10 \leq x<20$ & 1 & be discharged and/or re-injected \\
\hline & $20 \leq x<40$ & 1.5 & back to the reservoir. \\
\hline & $40 \leq x<60$ & 2 & \\
\hline & $>60$ & 4 & \\
\hline \multirow[t]{4}{*}{$7 \mathrm{H}_{2} \mathrm{~S}$ content (ppm) } & $<100$ & 0 & Carried hydrogen sulfide and must \\
\hline & $100 \leq x<300$ & 0.5 & be separated from hydrocarbons \\
\hline & $300 \leq x<500$ & 0.75 & because it is highly toxic \\
\hline & $>500$ & 1 & and corrosive \\
\hline
\end{tabular}


Table 2. Continue...

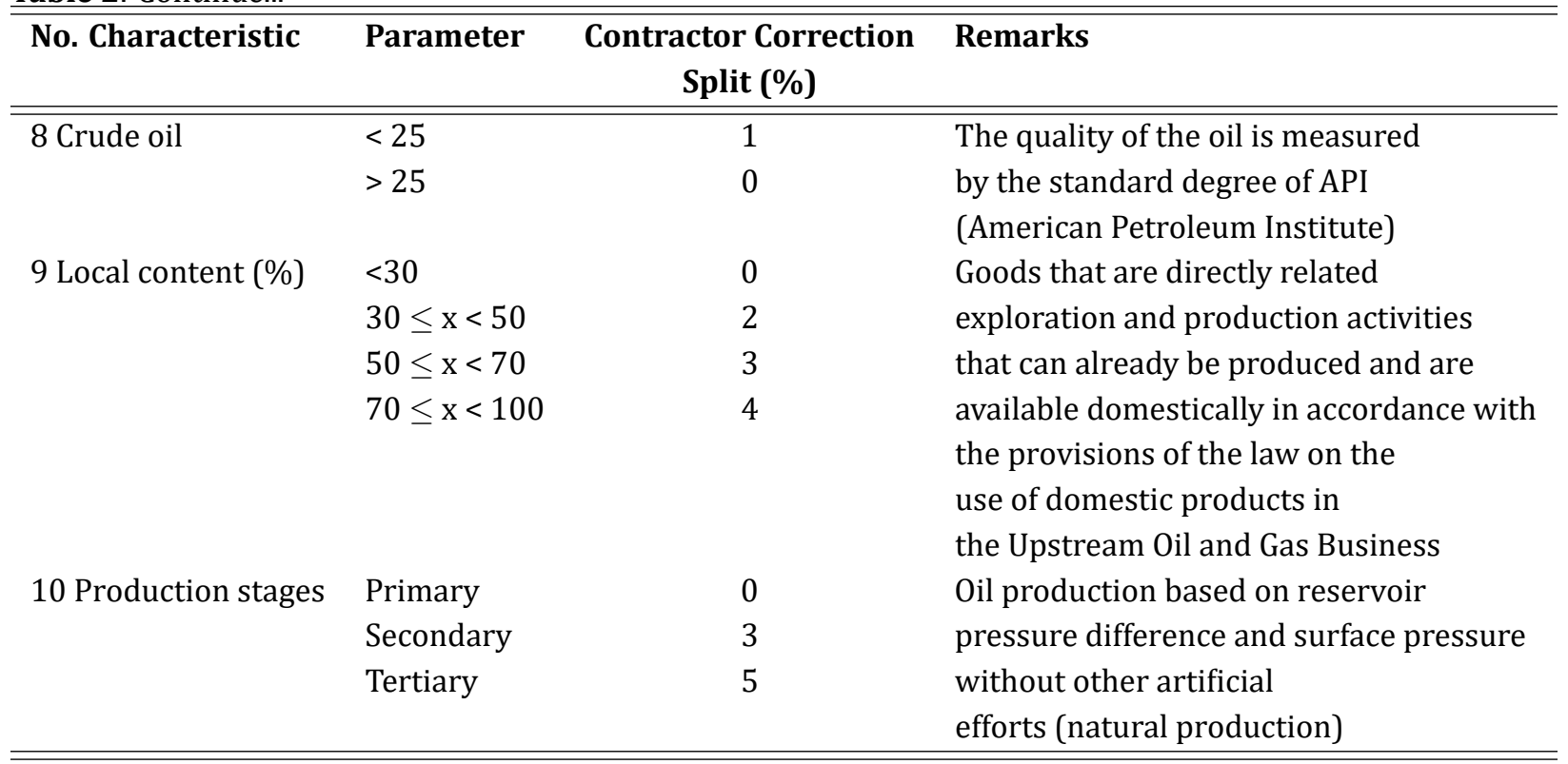

TABLE 3. Progressive Split (Indonesian Ministry of Energy and Mineral Resources, 2017)

\begin{tabular}{llcl}
\hline \hline No. Characteristic & Parameter & $\begin{array}{c}\text { Contractor Correction } \\
\text { Split (\%) }\end{array}$ & Remarks \\
\hline \hline 1 Crude oil Prices & $<40$ & 7.5 & World crude oil prices are \\
(US\$/barrel) & $40 \leq \mathrm{x}<55$ & 5.0 & based on Indonesian Crude Price (ICP) \\
& $55 \leq \mathrm{x}<70$ & 2.5 & \\
& $70 \leq \mathrm{x}<85$ & 0 & \\
& $100 \leq \mathrm{x}<100$ & $(-2.5)$ & \\
& $>115$ & $--.5 .0)$ & \\
& $<1$ & $-7.5)$ & Initial production is summed with \\
(MMBOE) & 5.0 & subsequent production at certain intervals. \\
& $10 \leq \mathrm{x}<20$ & 3.0 & For the working area, the money \\
& $20 \leq \mathrm{x}<50$ & 2.0 & has production status, the cumulative \\
& $50 \leq \mathrm{x}<150$ & 1.0 & number of production parameters is seen \\
& $>150$ & 0.0 & at the cumulative level of production \\
& & at the time of signing the contract. \\
\hline \hline
\end{tabular}

\section{RESEARCH METHODOLOGY}

This research methodology used is a comparison analysis between Cost Recovery and Gross Split Scheme. Then, we performed the economic calculations of both projects " $\mathrm{X}$ " and "Y" using project go-no-go decision from NPV, IRR, and payback period. After both economic calculations were per- formed, sensitivity analysis was carried out by changing the amount of oil and gas production, price, capital expenditure, and operational expenditure of three scenarios (low, base, high) to find out which sensitivity affects the economic value of this project. 


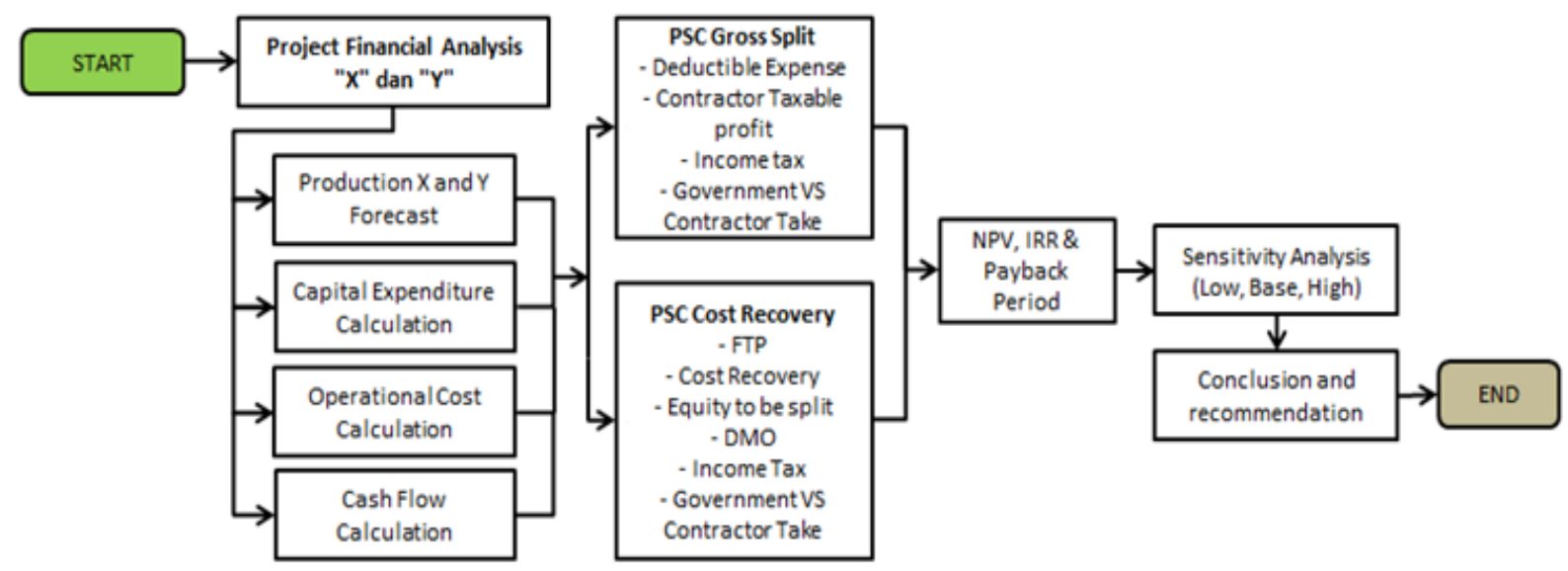

FIGURE 5. Methodology

\section{RESULTS}

\section{Case Study}

The case study takes on the block that became one of the first Oil and Gas Companies to implement the Production Sharing Contract (PSC) in 1971 in Indonesia and in 2017, the contract has expired and gross split implemented at this block. The case study takes 2 development projects called $X$ and Y project, both located offshore. Economic calculation only performed as stand-alone project and production facilities of other parts of this block do not affect this project's economic calculation. Discount rate of this economic calculation has been stated by company as $11.39 \%$.

With the use of double declining balance method with seven-year economic life for the assets of production facilities and the straight-line method with a five-year economic life for office equipment assets, the oil and gas product sharing contract in Indonesia actually provides accelerated depreciation due to asset- these assets can generally provide benefits longer than those specified above. By accelerating this depreciation, it will also increase the cash flow for the production sharing contractor that manages the oil or gas field.

\section{$X$ and $Y$ Projects}

The development of X project covers the scope of "greenfield", such as the construction of one braced monopod, installation of 12 "subsea pipes $10 \mathrm{~km}$ to the existing platform and drill 3 development wells that provide reserves of 51.87 BCF (Net) or 52.79 TBTU (Sales)". While the scope of the Y field project of "Greenfield", such as the construction of a tripod platform, installation of 12 "pipeline 3 phases for $13.5 \mathrm{~km}$, Recompletion 1 exploration well and drilling of two development wells, also the "Brownfield" jobs, such as modifications at existing facilities, tie-in spool installations, Y field provides reserves 3.9 MMBO of crude and 21.23 BCF or 23.35 TBTU of gas.

TABLE 4. Production forecast $X$ field (Gas only)

\begin{tabular}{lccccccc}
\hline \hline "X" Production Forecast & Reserve (BCF/TBTU) & $\mathbf{2 0 1 8}$ & $\mathbf{2 0 1 9}$ & $\mathbf{2 0 2 0}$ & $\mathbf{2 0 2 1}$ & $\mathbf{2 0 2 2}$ & $\mathbf{2 0 2 3}$ \\
\hline \hline Gas flow rate, MMSCFD & 51.87 & 10.0 & 30.0 & 30.0 & 30.0 & 26.3 & 15.7 \\
Gas flow rate, BBTUD** & 52.80 & 3.7 & 11.2 & 11.2 & 11.2 & 9.8 & 5.8 \\
\hline \hline
\end{tabular}

*Heating value $1,018 \mathrm{btu} / \mathrm{cu} \mathrm{ft}$

TABLE 5. Production forecast $Y$ field (Oil and Gas)

\begin{tabular}{lcccccccc}
\hline \hline "Y” Production Forecast & Reserve (MMBO/BCF/TBTU) & $\mathbf{2 0 1 9}$ & $\mathbf{2 0 2 0}$ & $\mathbf{2 0 2 1}$ & $\mathbf{2 0 2 2}$ & $\mathbf{2 0 2 3}$ & $\mathbf{2 0 2 4}$ & $\mathbf{2 0 2 5}$ \\
\hline Crude Rate MMBO & 3.9 & 1.35 & 3.48 & 2.11 & 1.31 & 1.00 & 0.83 & 0.59 \\
Gas flow rate, MMSCFD & 21.1 & 8.45 & 22.93 & 12.88 & 8.48 & 4.09 & 0.80 & 0.50 \\
Gas flow rate, BBTUD** & 23.4 & 3.4 & 9.2 & 5.2 & 3.4 & 1.6 & 0.3 & 0.2 \\
\hline \hline
\end{tabular}

*Heating value $1.100 \mathrm{btu} / \mathrm{cu} \mathrm{ft}$ 


\section{Capital expenditure and Operational Expenditure X \& Y Project}

In the $\mathrm{X}$ and $\mathrm{Y}$ projects, company created conceptual team consisting of various disciplines' engineers, such as reservoir, petroleum, production, subsea, commercial, safety, project engineers, to design and plan appropriate technologies to ensure the oil and gas production of the $\mathrm{X}$ and $\mathrm{Y}$ fields at the optimum, and has the highest project economic value. Project cost estimation data were taken from the history of previous similar field development and added future value of project cost when the project took place in 2017 till 2019. The total cost of the X field development project is estimated at USD 64.72 million which consists of: 37.14 million USD for the installation of pipes and construction of the platform and 27.58 million USD for the drilling of 3 (three) development wells. For the Y field development project, it is estimated at 85.3 million USD which consists of: 55.43 million USD for pipeline installation and platform construction and 29.98 million USD for the drilling of 1 (one) exploration well and 2 (two) development wells.
The investment cost of this project is divided into two, capital cost (tangible cost and intangible cost) which included the survey cost, FEED (front end engineering design), drilling \& exploration cost, facility cost, subsea pipeline installation, modification at existing platform, and the second is the operational cost, which consists of maintenance costs as long as the facility produces hydrocarbon, added with the abandoned site restoration cost. The difference of operational costs between the previous scheme (cost recovery) and the gross split is the contractor deductibles items, such as value added taxes, land and building taxes, and rent assets fees.

\section{Oil and Gas Price Estimation}

For the project economics calculations, forecasting of oil and gas prices is required to calculate cash flow. The commercial department of the contractor has performed two scenarios of crude prices: low case scenario prices and base scenario prices, but in this research, the author is advised by the expert to use the prices of low case because world oil prices have not stabilized.

TABLE 6. Forecast crude price 2017-2026

\begin{tabular}{lcccccccccc}
\hline \hline Forecast (US\$/BBL) & $\mathbf{2 0 1 7}$ & $\mathbf{2 0 1 8}$ & $\mathbf{2 0 1 9}$ & $\mathbf{2 0 2 0}$ & $\mathbf{2 0 2 1}$ & $\mathbf{2 0 2 2}$ & $\mathbf{2 0 2 3}$ & $\mathbf{2 0 2 4}$ & $\mathbf{2 0 2 5}$ & $\mathbf{2 0 2 6}$ \\
\hline Low Case & 45 & 47 & 49 & 50.2 & 51.4 & 52.6 & 53.8 & 55.1 & 56.4 & 57.8 \\
Base & 51 & 61 & 66 & 67.9 & 69.2 & 70.8 & 72.5 & 74.2 & 76 & 79.7 \\
\hline \hline
\end{tabular}

Different from crude prices, the gas prices are affected during the appointment seller agreement, where the selling price of gas from each customer of this block is different.
Therefore, author perform weighted from each gas price to the consumer by the amount of gas delivered.

TABLE 7. Gas Price average 2017 with escalation 3\%/year

\begin{tabular}{lllrl}
\hline \hline PT XYZ Costumer & $\begin{array}{l}\text { Gas Prices US\$/BTU-2017 } \\
\text { *Escalation 3\%/Yr ( a ) }\end{array}$ & $\begin{array}{l}\text { Gas Demand } \\
\text { (BTU/day) ( b ) }\end{array}$ & Weight (\%) ( c ) & Total (a x b) \\
\hline \hline 1 PLN & 7 & 33 & $33.7 \%$ & 231.0 \\
2 Pupuk Kujang & 5.73 & 49 & $50.1 \%$ & 280.8 \\
3 RU VI Balongan & 8 & 14 & $14.3 \%$ & 112.0 \\
4 PTGN & 7.42 & 1.3 & $1.3 \%$ & 9.6 \\
5 BBG & 4.72 & 0.5 & $0.5 \%$ & 2.4 \\
TOTAL & & 97.8 & $100 \%$ & 635.78 \\
Average gas prices (US\$/BTU) & 6.501 & & \\
*total (axb)/total (b) & & & \\
\hline \hline
\end{tabular}

\section{Gross Revenue and Contractor Cash Flow}

After production forecast, investment cost and oil and gas price estimation are identified. It can be calculated for the cash flow from each project, either cost recovery fiscal or gross split fiscal.
From Table 8, X project gross revenue total is 381.636 million USD and the contractor's gross cash flow will be different between gross split (108.147 million USD) and cost recovery (87 million USD). 
TABLE 8. Summary X project cash flow

\begin{tabular}{cccccc}
\hline \hline Year & \multicolumn{2}{c}{ Capital Expenditure (US\$M) } & \multicolumn{2}{c}{ Operational Expenditure (US\$M) } \\
\hline & Facilities & \multicolumn{2}{c}{ Driling } & Operating Cost (Cost Rec) & Operating Cost (Gross Split) \\
\cline { 2 - 6 } & & Tangible & Intangible & 0 & \\
\hline 2017 & 13,770 & & - & 4.186 & 13,770 \\
2018 & 23,328 & 3,138 & 24,450 & 4.297 & 9,629 \\
2019 & 50 & & - & 4.412 & 4,662 \\
2020 & & & & 4.531 & 4,780 \\
2021 & & & & 4.653 & 4,907 \\
2022 & & & & 4.779 & 5,037 \\
2023 & & & & 26.86 & 5,172 \\
Total & 31,148 & 3,138 & 24,450 & & 35,563 \\
\hline \hline
\end{tabular}

Table 8. Continue...

\begin{tabular}{|c|c|c|c|c|c|c|}
\hline \multicolumn{2}{|c|}{ Production } & \multicolumn{3}{|c|}{ Annual Lifting } & \multicolumn{2}{|c|}{ Prices US\$ } \\
\hline Crude & Gas & MBO & BBTU & MB OE & Crude & Gas \\
\hline MB OPD & MMS CFD & & & & & \\
\hline & 0.00 & & - & - & 45 & 6.5 \\
\hline & 10.03 & & 3,728 & 643 & 47 & 6.7 \\
\hline & 30.00 & & 11,154 & 1,923 & 49 & 6.9 \\
\hline & 29.99 & & 11,151 & 1,923 & 50.2 & 7.1 \\
\hline & 29.99 & & 11,151 & 1,923 & 51.4 & 7.3 \\
\hline & 26.32 & & 9,786 & 1,687 & 52.6 & 7.5 \\
\hline & 15.68 & & 5,828 & 1,005 & 53.8 & 7.8 \\
\hline
\end{tabular}

Table 8. Continue...

\begin{tabular}{ccc}
\hline \hline Gross Revenue US\$M & Contractor Cash Flow (Cost Rec) US\$M & Contractor Cash Flow (Gross Split)-US\$M \\
\hline- & -13.770 & $(15,147)$ \\
24,961 & -33.635 & $(42,198)$ \\
76,916 & 40.133 & 45,817 \\
79,204 & 26.405 & 34,176 \\
81,581 & 26.090 & 35,176 \\
73,738 & 29.641 & 32,732 \\
45,237 & 12.149 & 16,896 \\
381,638 & 87.01 & 108,147 \\
\hline \hline
\end{tabular}

Shown in Table 9, Y project total gross revenue is 370.569 million USD, smaller than $\mathrm{X}$ project gross revenue, but for the investment cost higher than X project. Gross Contractor cash flow is also bigger on gross split (77.5 million USD) and by cost recovery, only 49.34 million USD.

\section{Economic Summary Comparison}

The X project, which produces natural gas for $51.9 \mathrm{BCF}$, with an investment capital of 64.72 million USD, results in a larger net value of NPV net contractor take with the Gross Split scheme of 59.86 million USD, compared to the cost re- covery scheme which only gains NPV's 48.08 million USD with payback period in the same year 2020, while the IRR generated from the data analysis is not much different between the $50.13 \%$ Gross Split scheme and the Scheme Cost Recovery of $49.27 \%$. While Government Take or government revenue with the gross split scheme is much smaller by 173.2 Million USD, while with the cost recovery, it is 203 million USD.

Project $\mathrm{Y}$, which produces oil and gas $21.2 \mathrm{BCF}$ and 3.9 MMBO, with an investment capital of 85.3 million USD, resulted in a larger net value of contractor's NPV with a Gross 
Split scheme 37.49 million USD, compared to the cost recovery NPV scheme which only costed 21.62 million USD and with a payback period of the same year 2021, while the IRR generated from the data analysis is different between IRR $40.10 \%$ with gross split scheme and IRR $31.22 \%$ for cost recovery.

TABLE 9. Summary X project cash flow

\begin{tabular}{cccccc}
\hline \hline Year & \multicolumn{2}{c}{ Capital Expenditure (US\$M) } & \multicolumn{2}{c}{ Operational Expenditure (MMUS\$) } \\
\hline & Facilities & \multicolumn{2}{c}{ Driling } & Operating Cost (Cost Rec) & Operating Cost (Gross Split) \\
\cline { 2 - 5 } & & Tangible & Intangible & 0 & 70 \\
\hline 2017 & 702 & & - & 2,403 & \\
2018 & 24,029 & & & 4.476 & 10,927 \\
2019 & 30,658 & 4,710 & 25,270 & 4.587 & 4,987 \\
2020 & 50 & & & 4.702 & 5,105 \\
2021 & & & & 4.821 & 5,232 \\
2022 & & & 4.943 & 5,536 \\
2023 & & & 5.069 & 5,497 \\
2024 & & & 5.198 & 5,635 \\
2025 & & & 33.796 & 45,219 \\
Total & 55,438 & 4,710 & 25,270 & & \\
\hline \hline
\end{tabular}

Table 9. Continue...

\begin{tabular}{|c|c|c|c|c|c|c|}
\hline \multicolumn{2}{|c|}{ Production } & \multicolumn{3}{|c|}{ Annual Lifting } & \multicolumn{2}{|c|}{ Prices US\$ } \\
\hline Crude & Gas & MBO & BBTU & MB OE & Crude & Gas \\
\hline MB OPD & MMS CFD & & & & & \\
\hline 0 & 0 & - & - & - & 45.0 & 6.5 \\
\hline 0 & 0 & - & - & - & 47.0 & 6.7 \\
\hline 1.35 & 8.45 & 494.34 & 3,397 & 1,080 & 49.0 & 6.9 \\
\hline 3.48 & 22.93 & $1,271.80$ & 9,215 & 2,861 & 50.2 & 7.1 \\
\hline 2.11 & 12.88 & 772.42 & 5,174 & 1,664 & 51.4 & 7.3 \\
\hline 1.31 & 8.48 & 478.25 & 3,406 & 1,066 & 52.6 & 7.5 \\
\hline 1.00 & 4.09 & 363.66 & 1,644 & 647 & 53.8 & 7.8 \\
\hline 0.83 & 0.80 & 302.28 & 319 & 357 & 51.5 & 8.0 \\
\hline 0.59 & 0.50 & 213.71 & 202 & 249 & 56.4 & 8.2 \\
\hline
\end{tabular}

Table 9. Continue...

\begin{tabular}{ccc}
\hline \hline Gross Revenue MMUS\$ & Contractor Cash Flow (Cost Rec) US\$M & Contractor Cash Flow (Gross Split)-US\$M \\
\hline 0 & -0.70 & $(.77)$ \\
0 & -24.03 & $(26.43)$ \\
47,645 & -25.76 & 66.27 \\
129,293 & 41.40 & 33.39 \\
77,552 & 21.57 & 22.98 \\
50,824 & 14.46 & 14.65 \\
32,327 & 19.97 & 4.36 \\
19,209 & 1.59 & 2.01 \\
13,719 & 0.83 & 77.5 \\
370,569 & 49.34 &
\end{tabular}


While for Government Take or government revenue, similar to project X, the Gross Split scheme is much smaller by 162.2 Million USD, while with the Cost Recovery, it is 200 Million USD.

\section{Sensitivity Analysis}

The risk of a project is a collection of massive uncertainties that affect profits. The accuracy of the information of these magnitudes will affect the accuracy of the profit, while the decision is taken from the large and small profits (Partowidagdo, 2009).

TABLE 10. Economic summary comparison

\begin{tabular}{|c|c|c|c|c|c|}
\hline \multicolumn{2}{|l|}{ Economic Summary } & \multicolumn{2}{|c|}{ POD X } & \multicolumn{2}{|c|}{$\overline{\text { POD Y }}$} \\
\hline Contractor's & & Gross Split & Cost Recovery & Gross Split & Cost Recovery \\
\hline \multicolumn{6}{|l|}{ Economic Indicators } \\
\hline Project start & & & 2017 & & 2017 \\
\hline NPV11.39 & US\$M & 59.86 & 48.08 & 37.49 & 21.62 \\
\hline Payback & Year & 2020 & 2020 & 2021 & 2021 \\
\hline IRR & $\%$ & $50.13 \%$ & $49.27 \%$ & $40.10 \%$ & $31.22 \%$ \\
\hline First Production & Year & 2018 & 2018 & 2019 & 2019 \\
\hline End Economical Production & Year & 2023 & 2023 & 2025 & 2025 \\
\hline \multicolumn{6}{|l|}{ Evaluation Summary Forward Looking } \\
\hline BOE & MMBOE & 8.9 & 8.9 & 7.6 & 7.6 \\
\hline Gas & $\mathrm{BCF}$ & 51.9 & 51.9 & 21.2 & 21.2 \\
\hline Oil & MMBO & 0.0 & 0.0 & 3.9 & 3.9 \\
\hline Gross Revenue & US\$M & 381.6 & 381.6 & 370.6 & 370.6 \\
\hline Gross OPEX & US\$M & 35.6 & 26.9 & 45.8 & 34.7 \\
\hline Facilities Cost & US\$M & 37.1 & 26.9 & 55.4 & 55.4 \\
\hline Intangible Drilling Cost & US\$M & 24.4 & 24.4 & 25.3 & 25.3 \\
\hline Tangible Drilling Cost & US\$M & 3.1 & 3.1 & 4.7 & 4.7 \\
\hline Government Take & US\$M & 173.2 & 203.0 & 162.2 & 200.0 \\
\hline Contractor Cash Flow & US\$M & 108.1 & 87.0 & 77.1 & 50.4 \\
\hline Government Share of Gross Revenues & $\%$ & $45.38 \%$ & $53.20 \%$ & $46.86 \%$ & $53.98 \%$ \\
\hline Cost Recovery & $\$ \mathrm{~m}$ & 0 & 91.59 & 0 & 120.11 \\
\hline Total Cost/Gross Revenue & $\%$ & $26.28 \%$ & $24.00 \%$ & $35.41 \%$ & $32.41 \%$ \\
\hline Opex/boe & US\$ & 4.0 & 3.0 & 6.1 & 4.6 \\
\hline Capex/boe & US\$ & 7.2 & 7.2 & 11.3 & 11.3 \\
\hline Total Cost/boe & US\$ & 11.2 & 10.2 & 17.4 & 15.9 \\
\hline
\end{tabular}

Sensitivity Analysis is a study of how uncertainty over an output can be distributed to several sources of uncertainty in an input (Saltelli et al., 2008).

Sensitivity analysis is the goal to see how changes in the values of important variables affect the benefits. Variables that are often used for sensitivity analysis are as follows: amount of production, oil and gas price, amount of capital expenditure, and amount of operational cost to see how they affect NPV, IRR, and government take.

Net Present Value can be explained as the difference between the Present Value of the cash inflows and the Present Value of the cash outflows (Peterson \& Fabozzi, 2002). Shown in Figure 6, sensitivy analysis is performed for all variables to NPV contractor; it is seen that production and crude price variables are sensitive both in gross split and cost recovery, but the spread range is bigger on gross split scheme. This means that if the contractor can gain hydrocarbon production above target or Indonesian crude prices are high, the gross split scheme gives more profit than cost recovery for contractor NPV's.

IRR is one of the variables to make decision of a project worth to be developed or not, then variables will be changed from low case, base, and high case to find out which variables affected IRR.

Different from contractor's NPV and IRR sensitivity analysis, shown in Figure 8, variables production and crude 
prices are more sensitive to cost recovery and the spread is wider on cost recovery. It means by gross split, government revenues are smaller than old scheme, but that must be re- membered, the government no longer bears the cost recovery and also the project risk of oil and gas development is completely on the contractors.

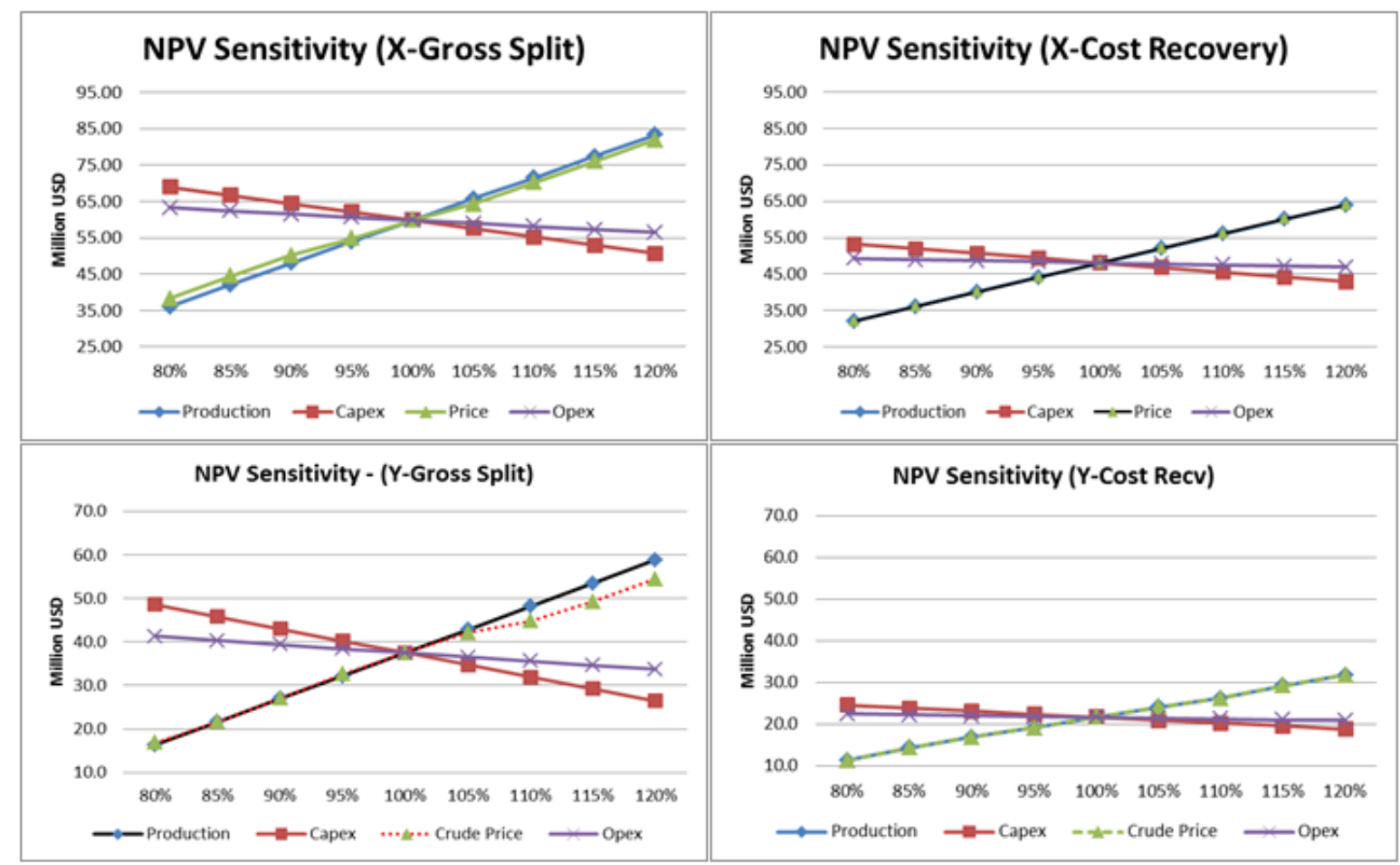

FIGURE 6. NPV sensitivity gross split \& cost recovery both $\mathrm{X}$ and $\mathrm{Y}$ projects

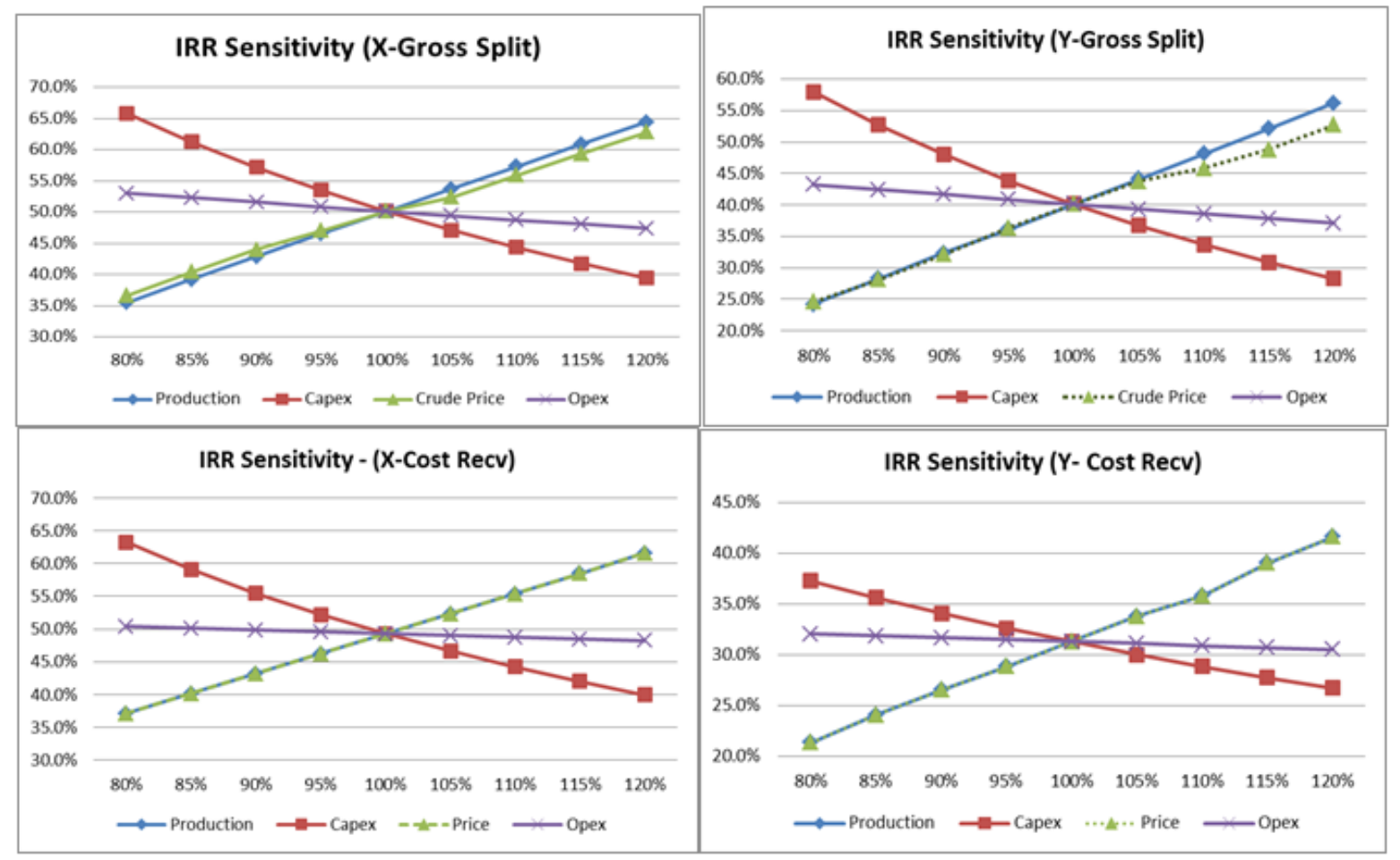

FIGURE 7. IRR sensitivity analysis gross split \& cost recovery both $\mathrm{X}$ and $\mathrm{Y}$ projects 
Shown in Figure 7, variables that are most sensitive to IRR are capital expenditure, amount of production, the crude prices, but same as with the NPV sensitivity analysis, the
IRR spread generated from the gross split scheme is wider than the cost recovery.

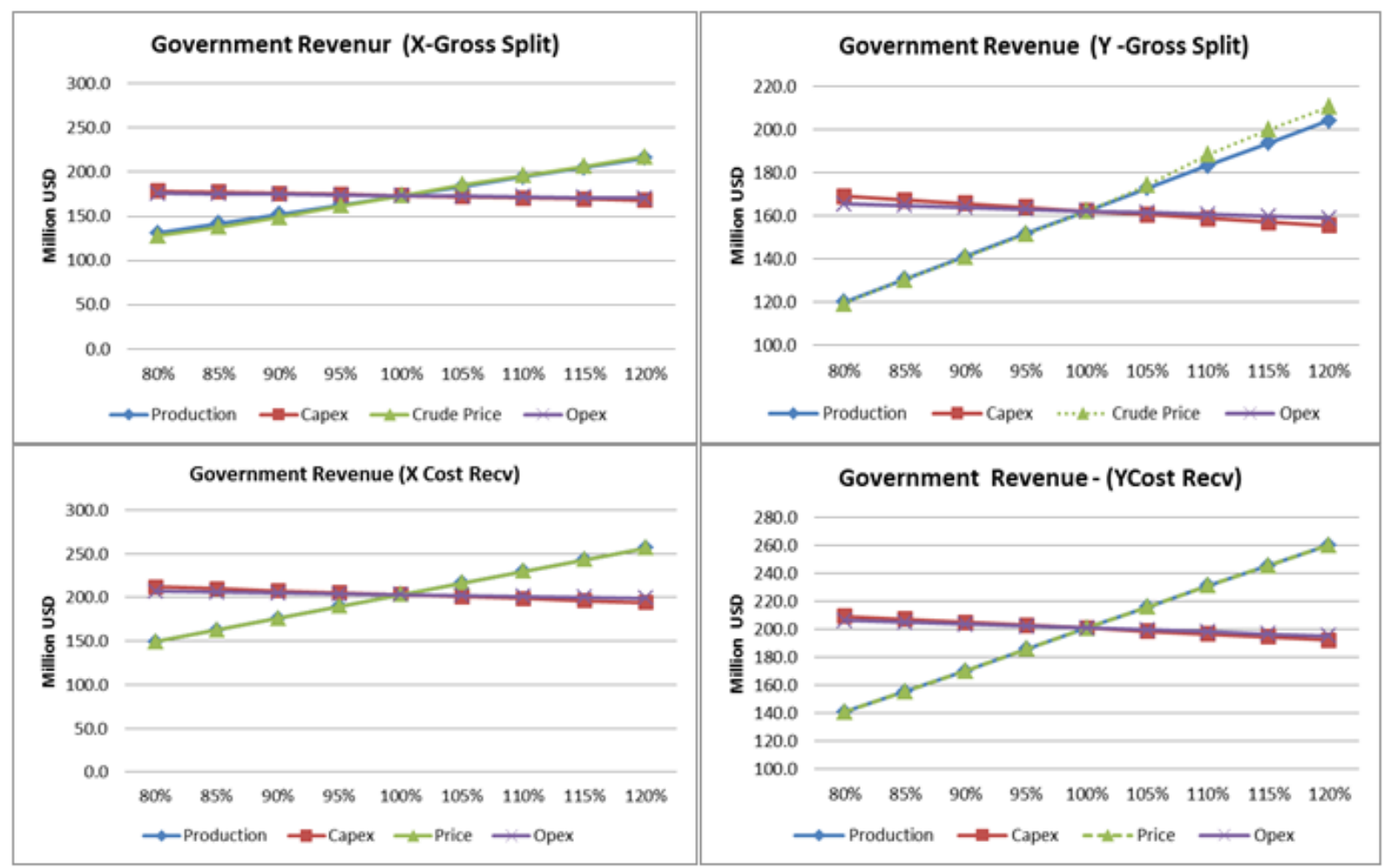

FIGURE 8. Sensitivity analysis government take

\section{DISCUSSION}

1. The Contractor or Investor must be observant in the Plant of Development plan of an Oil and Gas project. The capability of project feasibility study will determine the profit that will be achieved by the investor. The accuracy of the production forecasting, the selection of appropriate production facilities technology, and the timely project will be the determining factors for investor to gain profit under the PSC Gross Split.

2. The government needs to do a lot of simulations in oil and gas sharing contracts because the first case study of Gross Split is offshore and POD III where existing facilities exist, whereas the types of oil and gas field in Indonesia are very diverse and have different levels of difficulty, so the contract for the results of Gross Split in Indonesia should be attractive and gain benefit for both parties.

3. Further research can be considered by looking at an overall block contract not limited to a stand-alone project, but a whole block contract has difficulty levels that are combined with the new project. So, it can be seen whether the gross split PSC scheme is still compatible with.
4. At Indonesian Ministry of Energy and Mineral Resources (2017), Article 7 paragraph 1 (one) and paragraph 2 (two), the Minister of Energy and Mineral Resources shall be entitled to give an additional percentage of 5\% if the commercialization of the field does not reach a certain economic level. This can be further researched on for economic constraints, such as whether declared uneconomical and are entitled to an additional 5\%, as further research results could eliminate the possibility of misuse of this additional $5 \%$ to contractor.

5. This research is still limited to case studies in Oil and Gas field located offshore with MoEMR no. 8 Year 2017 on the share of Gross Split, while in the same year, the government issued an amendment of the Gross Split regulation, MoEMR no. 52 year 2017, where further research for the implementation of this new gross split needs to be analyzed.

6. Further research is expected to be able to compare gross split PSC in Indonesia with oil and gas contract of neighboring countries, so that it can give input, especially for Indonesian government, so that investors, both domestic 
and foreign, are still attracted to invest their money in Indonesia.

\section{CONCLUSION}

1. The current situation in Indonesia, as described in introduction where Cost Recovery continues to increase, while at the same time, world oil prices are declining, the PSC Gross Split model needs to be applied in Indonesia by taking stand-alone case studies in the above projects. In anticipation of changes in prices, production and especially the cost of project capital and operating costs of oil and gas field operations are no longer the responsibility of the Government, so that the share of government revenue sharing will always be maintained.

2. The mass media stated that the PSC Gross Split scheme is unfavorable for Investors. It must be returned to the contractor's efficiency and effectiveness to perform project development, where the implication of Gross Split is that the contractor will gain bigger profit as long as the efficiency and effectiveness of the project were implemented.

\begin{tabular}{llll}
\hline \hline PSC Scheme & Point of View & Advantage & Disadvantage \\
\hline Gross Split & Investor & Of all parameters: NPV, IRR All investment costs and oper- \\
& & $\begin{array}{l}\text { and Payback Period Gross Split ating costs incurred to contrac- } \\
\text { schemes with offshore area case tors' responsibilities, inefficien- } \\
\text { studies are superior to the Cost cies and ineffectiveness of project } \\
\text { Recovery scheme }\end{array}$ & costs and operational costs will \\
& & & be the contractor's losses because \\
& & & Gross Revenuent earned the initial
\end{tabular}

Government
POD approval process is easier and simpler, because SKK Migas only reviews the project's WPB WPB approval process is not as complicated as Cost Recovery scheme and requires faster time to process goods procurement. The complexity of project and the risks of oil and gas fields have been compensated with the Variable split, thus becoming an additional share for added the contractors' take

There is a certainty of the value of the profit sharing of oil and gas in the beginning of the contract (Gross Revenue). The Government Take/revenue is smaller than the Cost Recovery scheme. Government no longer burden by cost recovery and the state budget is not burdened with the capital cost of oil and gas projects, all oil and gas project development will not affected APBN 


\begin{tabular}{|c|c|c|c|}
\hline PSC Scheme & Point of View & Advantage & Disadvantage \\
\hline Cost Recovery & Investor & $\begin{array}{l}\text { The workload of supervision from } \\
\text { SKK Migas is reduced, because } \\
\text { project finance and operational } \\
\text { costs are the responsibility of the } \\
\text { contractor and the approval pro- } \\
\text { cess of the work plan and contrac- } \\
\text { tor cost budget will be faster. } \\
\text { The crude prices movement will } \\
\text { affected to government revenue } \\
\text { There is still a "guarantee" that } \\
\text { "Cost Recovery" fees paid by the } \\
\text { government, which will return } \\
\text { to contractor's take The value of } \\
\text { NPV, IRR and Payback periods ob- } \\
\text { tained by contractors is smaller } \\
\text { than the Gross Split PSC scheme } \\
\text { The movement of world oil prices, } \\
\text { the conditions of production op- } \\
\text { erations, the quality of produc- } \\
\text { tion the effect is not too big as in } \\
\text { gross split } \\
\text { Government The Government } \\
\text { Take of recovery scheme is bigger } \\
\text { than the Gross Split scheme. } \\
\text { Sometimes net Government } \\
\text { Take are not balanced with cost } \\
\text { recovery that government paid to } \\
\text { contractor } \\
\text { Cost Recovery cost is borne to the } \\
\text { State. } \\
\text { Project capital risk will be part } \\
\text { of the government's responsibil- }\end{array}$ & $\begin{array}{l}\text { The process of procurement of } \\
\text { goods with Cost Recovery re- } \\
\text { quires a longer time approval due } \\
\text { to the verification of the budget } \\
\text { value and approval from SKK Mi- } \\
\text { gas also the cost recovery are sub- } \\
\text { ject to be plan as state budged. }\end{array}$ \\
\hline
\end{tabular}

3. Government revenue is much smaller with the gross split scheme compared to the cost recovery scheme, but in the long term, the government is no longer burdened with cost recovery which annually burdens the APBN and the value can be allocated to the needs of other countries. Although this case study does not include complete one block economic calculation, which has different production charac- teristics, but only calculates stand-alone project, the results from data processing and analysis for both case studies $\mathrm{X}$ and $\mathrm{Y}$ projects are profitable for contractor and worth to be executed. The NPV's are positive in both schemes, IRR above corporate expectation ( $>15 \%$ ) and for the payback period in same year. 


\section{Acknowledgment}

The authors would like to thank all who have helped and participated in this research. The first one, author dedicated this research to his parents, wife, and beloved family who always give encouragement and full support; To my au- thor pak Imam Baihaqi for sharing his knowledge and his time with me; to all colleagues in Master Degree MMT ITS Jakarta Association Program, class of 2015; To Faculty of Business \& Technology Management, Institute of Technology Sepuluh Nopember in Surabaya.

\section{REFERENCES}

Ariyati, E. S. (2010). Analisis ketentuan-ketentuan di production sharing contract Indonesia dalam kaitannya dengan penerimaan negara minyak dan gas bumi (Unpublished master thesis). Universitas Indonesia, Depok, Indonesia.

BP. (2016). Bp statistical review of world energy. Retrieved from goo.gl/QqwwtB (accessed 10 October 2016)

Galawidya, D. A. (2008). Analisis perbandingan termin fiskal production sharing contract di indonesia, production sharing contract non cost recovery dan production contract di Malaysia (Unpublished master thesis). Universitas Indonesia, Depok, Indonesia.

Indonesian Ministry of Energy and Mineral Resources. (2017). Peraturan pemerintah esdm no. 8/2017. Retrieved from goo.gl/icCrTu (accessed 15 January 2018)

Johnston, D. (2007). Escaping the resource curse: How to evalate the fiscal terms of oil contracts. New York, NY: Colombia University Press.

Kementrian, k. (2016). Pendapatan negara bukan pajak, pendapatan sda migas apbn 2016 \& rapbn 2017. Retrieved from goo.gl/n9Gg3x (accessed 21 July 2017)

Lubiantara, B. (2012). Ekonomi migas: Tinjauan aspek komersial kontrak migas. Jakarata, Indonesia: Gramedia Widiasarana Indonesia.

Machmud, T. N. (2000). The indonesian production sharing contract: An investor's perspective. New York, NY: Kluwer Law International.

Nasir, A. (2014). Sejarah sistem fiskal migas Indonesia. Jakarta, Indonesia: Gramedia Widiasarana.

Partowidagdo, W. (2009). Migas dan energi di indonesia: Permasalahan dan analisis kebijakan. Bandung, Indonesia: Development Studies Foundation.

Peterson, P. P., \& Fabozzi, F. J. (2002). Capital budgeting: Theory and practice. New York, NY: John Wiley \& Sons.

Reilly, F. K., \& Brown, K. C. (2002). Investment analysis and portfolio management. Beijing, China: Citic Publishing House.

Saltelli, A., Ratto, M., Andres, T., Campolongo, F., Cariboni, J., Gatelli, D., ... Tarantola, S. (2008). Global sensitivity analysis: The primer. New York, NY: John Wiley \& Sons.

Yoshino, N., \& Alekhina, V. (2016). Impact of oil price fluctuations on an energy-exporting economy: Evidence from russia. Journal of Administrative and Business Studies, 2(4), 156-166. doi:https://doi.org/10.20474/jabs-2.4.2 